\title{
SZEMLE
}

\section{„Hiszen Én, ha AZT MONDOM Tej..., AVAGY BARKÁCSOLÁS AZ OKTATÁSBAN}

\author{
CSIKAI ILDIKÓ
}

Jenny Ozga, Peter Dahler-Larsen, Christina Segerholm \& Hannu Simola: Fabricating Quality in Education. Data and Governance in Europe. London, 2011. 190 p.

Routledge. ISBN 978-0415583428

Hervay Gizella Levél belyett címü írása, melyből a cím első részét idéztem, többek között egy olyan egyszerűen bonyolult témáról szól, mint a kommunikáció buktatói, és a félreértések eredetének egy lehetséges magyarázatát nyújtja. Hervay költői képei lenyűgözően mutatják, hogy előzetes tapasztalataink, nevelési különbségeink, vagy egyéb, minket ért hatások miatt egy-egy szó, kifejezés mennyire más gondolatokat ébreszthet bennünk: „... hiszen én, ha azt mondom: tej, nagy diófát látok, a lomb közt kis égdarabok, a fa alatt kerti asztal, pohárban tej, tündöklik a tej, a táj. De lehet, hogy ö arra emlékezik, hogy nem kapott tejet, nem volt, és az anyja messze volt, és megütöd a szóval... Ha megtalálnám! Sose merném többé kimondani a szót: szeretlek! Csak azt mondanám: vonat, mert talán állomás mellett lakott, és évein át-átzakatolt a vonat, félelmet hozott és sóvárgást távoli tájak felé..."

Jenny Ozga és szerzőtársai könyvét olvasva újfent szembesülhettem azzal, hogy milyen nehéz müfaj a fordítás. Nem csupán azért, mert sokszor jelentésbeli árnyalatok óriási különbségeket eredményezhetnek még akkor is, ha alapos szakmai ismeretekkel rendelkezünk az adott témakörben, és nyilvánvaló, hogy egy-egy nyelv szavakból szőtt kincsestára igen-igen kultúrafüggő. Innen már csak egy lépés, hogy elképzeljük, mekkora vállalkozás megállapodásokat, rendelkezéseket, törvényeket, az európai-bábeli nyelvrengetegben olyan szinten egységessé, érthetővé tenni, hogy mindenki hasonlóképpen értelmezze. És az oktatás szintetizálása még ennél is bonyolultabb vállalkozás. Már az első fejezet (Változó térbeli és társadalmi kapcsolatok az oktatásban Európában) szerzői nem csupán területi határokról tesznek említést, hanem azokra a gondolathatárokra is felhívják a figyelmünket, amelyeket a nemzetállamok történelme, nyelvhasználata és népszokásai képeznek.

Füst Milán szerint „a házasság négy lábon álló asztal. Először is szeretnetek kell egymást. Másodszor hasonló kell, hogy legyen az életstílusotok. Harmadszor meg kell értenetek egymást szexuálisan. S negyedszer, a házasság gazdasági kapcsolat is. A négy láb tehát a szeretetteli lelki kapcsolat, a második a szellemi hasonlóság (életstílus), a harmadik a kölcsönös, kielégítő szexualitás, a negyedik a gazdasági közösség és bizalom." Ha asz- 
talnak tekintjük az EU-t, vajon hány lába lehet annak a képződménynek, amelynek még csak közös nyelve sincs? Önmagában már ez elegendő ahhoz, hogy állandóak legyenek a félreértések, elértések. A szerzők is felvetik ezt a gondolatot egyrészt eltöprengve azon, hogyan fordítódik le (át) az „Európa-ötlet” fogalma a különböző nemzeti tereken, és fordítva, azaz a különféle szinteken keresztül haladó politikai elképzelések, tehát a helyi, az európai, a globális gondolatok fordításai és kontextusba helyezése milyen problémákat vet fel, és milyen nehézségeket jelent a közös „menetrend”, értékrend létrehozása.

Philip Coombs oktatásgazdaságtani szakértőként a hatvanas évek végén lenyügöző információ- és tényanyag nyomán végzett nemzetközi elemzést, és mutatott rá az oktatási rendszerek válságára. Már akkor világossá vált, hogy a társadalmi, gazdasági, technikai fejlődés ütemét és színvonalát az oktatás képtelen követni. Coombs 1971-ben magyarul is megjelent munkájában egyrészt a nemzetközi együttmüködésben látta a megoldást, másrészt az ezek finanszírozásához szükséges pénzügyi források emelésében. $\mathrm{A} z$ egyetemek szerkezeti átalakítását is sürgette, azaz a fejlődő országokban új intézmények alapítását, képzési struktúrák kialakítását, megvalósítását, a kutatási lehetőségek erősítését, az egyetemek közötti együttmüködések szervezését különböző dimenziókban. Érzékeltette, hogy a megoldást több szinten és több módon kell elkezdeni.

A 90-es évektől kezdve szinte egymást követték azok a dokumentumok, amelyek felhívták a figyelmet a társadalmi viszonyok átalakulására, az oktatási stratégiák megváltoztatásának szükségességére, és amelyek többsége kiútként a tanuló társadalom eszméjének, az élethosszig tartó tanulás megvalósításának, az általános tudás elterjedésének, valamint a szaktudás elismerésének összehangolását fogalmazta meg. Előtérbe került a dolgok megértésének, a kreativitásnak, az ítéletalkotásnak és a döntés képességének fontossága, a nyelvtudás, az információáramlás fejlesztése, a megfelelő információnyújtás, a tájékoztatás és orientáció, az ifjúságvédelem, valamint az, hogy az egyéni képességek és szükségletek alapján mindenki számára olyan intézményekben legyen elérhető az oktatás, ahol a már megszerzett kompetenciákat elismerik, illetve lehetővé teszik a mobilitást.

Jacques Delors irányításával 14 kiváló tudós, egyetemi tanár, politikus, valamint rangos szervezetek, intézmények részvételével zajlott munka eredményeként látott napvilágot a L'éducation, un trésor est caché dedans (magyarul három évvel később jelent meg Oktatás rejtett kincs ${ }^{1}$ címmel). $\mathrm{Ez}$ a publikáció kijózanít, magával ragad, hitet ad és felébreszti a felelősségérzetünket önmagunkért, a szeretteinkért, a társadalomért; és figyelmeztet, hogy rengeteg tennivalónk van, és még közelebb visz bennünket ahhoz, hogy megérthessük az Európában, illetve a nagyvilágban zajló folyamatokat, a változtatások szükségességét. Felhívja figyelmünket arra, hogy hiába a csodálatos tudományos-technikai fejlődés, ha bizonyos területeken óriási elmaradásban vagyunk. Láttatja, hogy kölcsönös függésben vagyunk egymástól, és ha saját magunkkal, környezetünkkel sem tudunk békében meglenni, hogyan tudnánk másokkal, a világgal. Az ellentétek felvillantásával erősíti bennünk is a feszültséget (hagyományos és modern, globális és lokális, az ismeretanyag tágulása és a befogadóképesség korlátai), majd feloldja azt, mintegy megoldásként vázolva

\footnotetext{
A földmüves és a gyerekei c. La Fontaine-mesére utal a címe: „Vigyázzatok az örökség eladásával [mondja a földmüves a gyermekeinek], amit a szüleink örökül hagytak ránk, az a bennünk rejlő kincs."
} 
az egész életen át tartó oktatás országonkénti kialakításával kapcsolatos feladatok modelljét, kijelentve, hogy ez a koncepció a 21. századba való lépés egyik kulcsa (Delors 1999: 16).

Az oktatás, ami egyre inkább mint tanulás jelenik meg világszerte, és az annak rendszereivel kapcsolatos kutatások ma még nem igazán lépik át a politikai határokat. Míg a történelem során éveket, évtizedeket töltöttek (és tölthettek el, mert igen-igen lassan érlelődtek a változások) egy-egy kultúra megismerésével a kor „oktatásszakértői”, utazva, költözve egyik államból a másikba; ma (amikor percenként születnek tudományos cikkek) nemhogy az Európán belül születő eredmények követése vált nehézkessé - bár technikailag minden lehetőség adott -, hanem olykor egy-egy országon belül is átláthatatlan a helyzet. A konferenciákon, szakmai találkozókon bámulatos prezentációk ezrei ragyognak fel, a szintetizálás fáradságos munkája azonban gyakran elmarad. Ha mégis átlépi a politikai határokat egy-egy kutatás, és valami konszenzus születik, sőt akár megoldási javaslat, mint a Delors vezette munka nyomán, úgy a programok megvalósulása elé gördülnek akadályok. A 2011-ben született kötet szerzői, akik közül néhányan már korábban is sikeresen alkottak együtt, kiváló példáját mutatják annak, hogy korunkban is lehetséges eredményes interdiszciplináris, egyszerre kvalitatív és kvantitatív kutatást folytatni, bevonva az oktatás, a politikatudomány tudósait, és megfejelve azzal, hogy az értékelést is komoly szakértőkre bízták.

Richard Feynman szerint a tudomány lehet valami felfedezésének a különleges módja, de lehet egyfajta tudásmennyiség is, és jelentheti valamilyen felfedezés hasznosságát, azaz, hogy egy-egy felfedezés mire tesz bennünket képessé (Feynman 2001). Szinte szóról szóra ugyanígy fogalmaz kor- és honfitársa, Robert $\mathrm{K}$.
Merton, aki tudományon olyan módszereket ért, melyek használatával tudásunk gyarapodik, illetve az alkalmazásuknak köszönhetően születő ismeretmennyiséget, valamint „egy sor kulturális értéket és szokást, amely a tudományosnak nevezett tevékenységeket szabályozza, vagy az előbbiek bármely kombinációját" (Merton 2002: 635). Kettejük nyomán azt mondhatnánk, hogy a könyv az európaiasítás és a kormányzás kulcsfontosságú témái és azok kölcsönös függősége köré szervezödik, és ezt az európai minőségbiztosítási és értékelési (QAE) rendszerek által termelt és használt adatok felhasználása mentén mutatja be. Ám sokkal érdekesebb annál, hogy ennyivel megelégedjünk. Felveti például a minőség fogalmát, felvázolja, hogy milyen változásokon ment keresztül az évszázadok során. Rámutat arra az összefüggésre, hogy az iparosodás elválasztotta az egyént a teljes termelési folyamatra vonatkozó felelősségtől, és ezzel megnyílt az út a selejt elóállítására. Ezért, ennek hatására, fejlődtek ki a mintavételi technikák, a minőségbiztosítási rendszerek. A minőséget nem lehet a véletlenre bízni. „Se nem istenadta, se nem természetes. A jó irányítás és a szervezet ügye ... a minőség statisztika." (4. o.) És a minőség mint funkció egy mindent átfogó és magába foglaló hatáskörré képes válni. Több kérdést is felvethet ez a gondolatmenet. Vajon az európai közös oktatás kialakításáért ki vállal felelősséget? Lehet-e az uniós minőségbiztosítási rendszereknek szervezetfejlesztő hatásuk?

A szerzők a különböző oktatáspolitikai nemzeti rendszereken belüli és egymás közötti kormányzási feszültségekről tesznek említést, valamint arra is felhívják a figyelmünket, hogy a nemzetállamok kormányzásának új irányítási formaként „fentről lefelé, lentről felfelé és egymás mellett is" kell müködnie egyszerre $(6,0$.$) , tehát optimális$ esetben a korábbi hierarchikus elrendezé- 
sű rendszereknek új hálózati, horizontális és rugalmas formákká kell válniuk. Az új irányítási formák közül azokat tartják jónak, amelyek támogatják az európaizálási folyamatot, lehetővé teszik, hogy az adatszabályozás talaján új európai oktatáspolitikai tér szülessék. Innovatív érveket sorakoztatnak fel az adat- és teljesítményértékelés kapcsolatának, összefüggéseinek hatásáról, melyet az európai oktatási térség irányítására fejt ki. Feszegetik, vajon a QAE-rendszerek tényleg hozzájárulnak-e a rendszer és az egyén fejlődéséhez. Vitatják azt, hogy az oktatás kimozdult volna az intézményesített rendszerek hagyományos kereteiből, „hogy új, folyékony, rugalmas és nemzeteken átívelő jelenséggé váljon, mint tanulás" (7. o.). Milyen mértékben került Európa a fordítás hatása alá ${ }^{2}$ (6. fejezet); lehetséges-e ötletek összebarkácsolásáról beszélni, amikor az európai oktatásra gondolunk; hogyan lehet a helyi kormányzás szerepét érvényesíteni; a tanárok hogyan viszonyulnak a minőség biztosításához és ellenőrzéséhez, illetve ezek hogyan hatnak vissza a munkájukra? A szerzők egyfajta nemzetköziesedést érzékelnek, „az emberek, a kultúra, az élelmiszer, az információ, a közlekedés regionális és világméretü mozgása hatást gyakorol a határokon belüli mentalitásra, az irányításra és az oktatás szervezésére mint szolgáltatásra és a kutatásra is." (12.0.)

A könyv tíz fejezetből áll, azonban valójában három témakörre koncentrál. $\mathrm{A} z$ első hat fejezet elsősorban az európaiasítással foglalkozik, míg a következő három közvetlenül kormányzati kérdésekkel, valamint azokkal a hatásmechanizmusokkal, amelyek az adatközpontú kormányzást, a helyi hatóságokat és iskolákat érintik. A tizedik fejezetben, illetve har-

2 Már a Bevezetésben is hangsúlyt kap ez a témakör, egyenesen anglicizálásnak nevezik a szerzők azt a folyamatot, amely során nemzetközi dokumentumok, sőt publikációk is születnek. madik témakörben a tanárok véleményéről olvashatunk.

Sok víz lefolyt már Európa folyóin a könyv megszületése óta, az európai oktatás területén is temérdek változás történt. A minőségellenőrzés továbbra is rendületlenül folyik, termelödnek az adatok, de hogy képesek vagyunk-e egy egységes európaiasított oktatási rendszer kialakítására, amely valamennyi szereplő számára egyformán tetszetős és eredményes, és amely ebben a felgyorsult világban segíti a túlélést, ez igen erősen megkérdőjelezhető (az Erasmus, az Erasmus + és társai dacára).

És ha azt mondom: európai oktatás... Leonard Cohen Anthem címü dalából az alábbi sort idézik a szerzők: „Mindenen van egy repedés, egy rés, és a fény azon jut keresztül..." Igen optimista gondolat, bár nem árt figyelembe venni, hogy az oktatás nagyon sok szereplőt érintő terület, és a különféle oktatási rendszerek összehangolása napjainkban szinte lehetetlennek látszó feladat. Bennem egy egészen más gondolatmenet indul el, ha az európai oktatásra gondolok, egy kínai közmondás nyomán: „aki tigrisen lovagol, fél leszállni”. Ugyanakkor kívánatos lenne persze olyan repedést felfedezni, amelyen keresztül az európai oktatás olyan megvilágításba kerül, amely a szakemberek számára lehetőséget teremt újabb, a gyakorlatban is alkalmazható megoldások megtalálására, hogy senki ne érezze azt, hogy tigrislovaglás manifesztálódik a közös európai oktatás kialakításának sok évtizedes kísérletei folyamatában. Mert egyelőre még úgy tünik, hogy az egyre több energiabefektetés hatására sem jön eredmény, és már veszélyesebb kiszállni (csak kiugrani lehet, mint momentán az Egyesült Királyság), mint hajtani a lehetetlent tovább és tovább. 


\section{IRODALOM}

Bagdy E., Belső N. \& Popper P. (2004) Szeretet, szerelem, szexualitás. Budapest, Sziget.

Cоомвs, P. H. (1971) Az oktatás válsága. Budapest, Tankönyvkiadó.

Delors, J. (1999) L'Éducation: un trésor est caché dedans. Paris, UNESCO.

FÁbRi Gy. (2015) A tudomány társadalmi percepciója Magyarországon. Századvég, Vol. 20. No. 77. pp. 31-59.
Feynman, R. P. (2001) A dolgok értelme. Budapest, Akkord.

Merton, R. K. (2002) A tudomány és a demokratikus társadalmi struktúra. In: R. K. Merton (ed.) Társadalomelmélet és társadalmi struktúra. Budapest, Osiris. pp. 634-644.

A cikk a Creative Commons Attribution 4.0 International License (https://creativecommons.org/licenses/ by/4.0/) feltételei szerint publikált Open Access közlemény, melynek szellemében a cikk bármilyen médiumban szabadon felhasználható, megosztható és újraközölhető, feltéve, hogy az eredeti szerző és a közlés helye, illetve a CC License linkje és az esetlegesen végrehajtott módosítások feltüntetésre kerülnek. (SID_1) 